IJSSP

$30,9 / 10$

532

Received 15 March 2010

Revised 17 May 2010

Accepted 20 May 2010

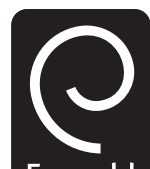

Emerald

International Journal of Sociology and Social Policy

Vol. 30 No. $9 / 10,2010$

pp. $532-544$

(C) Emerald Group Publishing Limited 0144-333X

DOI $10.1108 / 01443331011072280$

\section{Parental leave: from perception to first-hand experience}

\author{
Diane-Gabrielle Tremblay \\ Téluq-UQAM, Montreal, Canada, and \\ Emilie Genin
}

\section{École de relations industrielles, Université de Montréal, Montréal, Canada}

\begin{abstract}
Purpose - Paid parental leave for both mothers and fathers has fed countless debates. Four years after the implementation of a new parental leave policy in Quebec, this paper aims to assess how parental leave is perceived in the workplace.

Design/methodology/approach - Using data from employee surveys carried out in a municipal police service, the paper employs analysis of variance techniques to compare the perception of parental leave within two groups of respondents: those who had gone on parental leave and those who had not. Findings - The findings highlight significant differences between the perceptions of parental leave entertained by the respondents who have taken it up and those who have not yet experienced parental leave.

Social implications - Analysing these differences has produced extremely interesting findings: adopting a public policy is not sufficient; organisations need to make employees feel supported in taking parental leave if they really want the policy to achieve the targeted results.

Originality/value - Paid parental leave is relatively new in Europe and almost non-existent in North America and few studies have been carried out to measure their perception in the workplace. This research shows how important it is to follow the use of the policy to make sure that it does not have negative impacts for those who use it.
\end{abstract}

Keywords Maternity leave, Paternity leave, Quality of life, Job satisfaction, Police

Paper type Research paper

\section{Introduction}

In the past few years, parental leave for both mothers and fathers has fed countless debates in the wake of the European Community's efforts to change the existing maternity leave and to introduce various modifications, including paternity leaves. With the exception of the USA and Australia, almost all developed countries have parental leave. A few have paid paternity leave (especially Scandinavian countries like Sweden, Finland, Norway and Iceland) while other countries have parental leave which can be taken up in one form or another or shared by both parents (Moss and O'Brien, 2006). In the Canadian province of Quebec, the administration and financing of parental leave has been under provincial jurisdiction since 2006. A number of modifications have subsequently been made to the Canadian parental leave policy: a period of three to five weeks of paid leave is allowed for the father and greater flexibility is available for taking up the leave (Tremblay, 2009).

Four years after the implementation of this new parental leave policy in Quebec, we set out to assess how it has been perceived in the workplace. We examined the police sector, a traditionally male, stress-laden environment, where a good portion of the workforce (between a quarter and a third, depending on definition and source; cf. Tremblay, 2004) is affected by variable work schedules. Male work environments are not often open to family-friendly policies (Tremblay, 2003); however, changing mentalities in Quebec has given greater value to parenthood and men seem to want to be increasingly involved in their families (Conseil de la Famille et de l'Enfance, 2008; Doucet et al., 2009; Marshall, 2006). Moreover, since women were admitted in the police force 25 years ago 
their numbers have steadily increased even though they remain a minority. The extended parental leave policy implemented in Quebec is in keeping with these social evolutions and it is therefore relevant to investigate the perception of this type of leave in the police sector.

Parental leave is designed to allow parents to concentrate on family matters for a certain period, to keep their job and to return to their paid employment afterwards without a problem (Doucet et al., 2009). The findings of our research, however, reveal that this is not always the case and that parental leave is sometimes perceived as a negative element in career development. Recent studies on work-life balance issues (Duxbury and Higgins, 2003; Tremblay, 2003, 2004) focused on work-time flexibility and dealt less with the impact of going on parental leave. Since the parental leave policy in Quebec is rather new (as in many other places) and studies on long parental leaves and on paternity leaves are scarce, it is important to see how parental leave is used and to observe the consequences of its use.

After reviewing the literature on parental leave and on organisational support for work-life balance, we will present our research design. Our findings highlight the significant differences between the perceptions of parental leave of respondents who have taken it up and of those who have not done so; and as a result they bring to light the impact that the management of this public policy has on its use. Analysing the effect of the policy management is extremely interesting for those organisations and policy makers who wish to support employees with parental leave and work-life balance. In addition, our findings underline the fact that the formal offer of leave is not enough: organisational support is needed to make sure employees feel the leave is accessible and that taking it will not have a detrimental effect on their career.

\section{Parental leave in Quebec}

While working environment arrangements are generally in the employer's discretion in English-speaking countries, most European countries support parents with public policies or tools aimed at improving work-life balance (Cette et al., 2007). In Canada, maternity leave has existed since 1971. The six months of parental leave was extended to one year in 2001 and can be taken up or shared by both parents (Doucet et al., 2009).

With respect to family policies, the province of Quebec stands out as a North American exception; its public policies have long supported work-life balance (Cette et al., 2007). In January 2006, Quebec introduced a new parental leave programme to promote professional equality among women and men regardless of their employment status. The programme allows parents to benefit from a flexible parental leave and pays 50 to 75 per cent of the salary depending on which of the two programme options is chosen (Doucet et al., 2009). Quebec's programme also provides a three-to-five-week period of paid paternity leave that is non-transferable to the mother. The nontransferable paternity leave and the possibility to share the parental leave are clearly intended to encourage men to participate in parental responsibilities while children are young. The presumption is then that a man who takes this leave would later participate more in his child's education (Conseil de la Famille et de l'Enfance, 2008), and that this participation would benefit both the child's development and his own work-life balance (Marshall, 2008). Indeed, the participation of men in family responsibilities, in addition to women's access to the labour market, children's rights and concern about the fertility rate in Quebec, was an important factor in designing and implementing the new programme (Doucet et al., 2009; Marshall, 2008). As Lewis and Campbell (2008) noted, sharing the responsibility for childcare within the household creates a particularly 
IJSSP

$30,9 / 10$

difficult issue: there is tension between the individual's real freedom to choose and gender equality. Are women really free to choose to go on parental leave? For this reason, the government of Quebec introduced a non-transferable leave aiming at tackling the issue of inequity between the genders.

In Canada as well as in other industrialised countries, a significant increase in the activity of women with young children within the workplace can be observed (Doucet et al., 2009). While some parents quit paid employment for a few months or a few years to care for their young children and with most households today being headed by two active parents (Almey, 2007), the majority of women with children under two years of age are active in the labour market (Marshall, 2006). It is understood that parental leave is intended to make both parents available to their young children but mothers take advantage of it in larger numbers and over longer periods (Marshall, 2003). Indeed, in Quebec, mothers take on average ten to 12 months of leave, while men take on average seven weeks. Since the new parental leave system was introduced in Quebec the positive effect that a non-transferable paid paternity leave can and does have on the participation rate of fathers (Marshall, 2008) has been clearly demonstrated. In 2006, 56 per cent of fathers eligible for paternity leave took advantage of the programme and in 200870 per cent of fathers did so, while only 32 per cent had done so in 2005 (when the leave was transferable to the mother); in our view, this clearly indicates how a non-transferable paid leave is an important factor in the participation of fathers in parental leave.

Parental leave is designed to allow the parent to return to employment without difficulty (Doucet et al., 2009). However, research shows that several organisational and cultural factors contribute to the success or to the failure of family-friendly policies (Fusulier et al., 2006). Since taking up leave or making use of other family-friendly policies is sometimes perceived as having a negative impact on one's career (Fusulier et al., 2008) the benefits that may be expected from these policies can be overvalued. British research conducted by Mumford and Budd (2006) shows that there is a disparity between the presence of a work-life balance policy and the employees' perceptions of its accessibility. The authors argue that statistics on the existence of family-friendly policies significantly overstate the extent to which such policies are really accessible to employees. They also indicate that the discrepancy between formal availability and actual usage should be the subject of future research, which is why we wanted to look into perceptions and intentions to avail themselves of these policies.

\section{Work-life balance and organisational support}

A number of studies report that parents complain about time constraints, especially the parents of young children under six years of age (Conference Board of Canada, 1994; Frederick, 1995; Tremblay, 2004). Parents also complain about work-family conflicts resulting from time pressures (Stephens and Sommer, 1996). Greenhaus and Beutell (1985) define the work-family conflict as the incompatibility between work requirements and family obligations such that one's involvement in the former constrains participation in the latter. Conflicts crop up when the individual perceives his/her family expectations as being at odds with that of his/her professional role(s) and vice versa (Frone and Rice, 1987). Family-friendly policies are usually designed to offset or to ease the tension between workers' family and professional roles and responsibilities; this is the case for parental leave.

A number of studies have identified the work environment factors that influence the work-family conflict. Research has identified the presence of family-friendly policies, the support of managers, supervisors and the support of colleagues (Conference Board 
of Canada, 1994; Duxbury and Higgins, 2003; Kossek and Ozeki, 1998; Rothbard et al., 2005). Other variables likely to affect how work-life issues are dealt with are the sector of industry and the professional category to which the respondent belongs. Indeed, researchers have shown that managers and other professionals are less satisfied with their work-life balance than other workers (Duxbury et al., 1993; Elliott et al., 2001; Frederick and Fast, 2001; Galinsky et al., 2001). It is for this reason that we focused on a demanding work environment - policing - known for its variable work schedules and the stress involved.

Other researchers have drawn attention to the impact of organisational culture, and to the behaviour and attitude of colleagues and supervisors with regards to problems encountered in articulating professional and personal responsibilities (Allard et al., 2007; Caussignac, 2000; Chenevier, 1996; Haas et al., 2002; Lewis, 2001). Generally speaking, the manager's negative attitude stresses the employee, generates dissatisfaction and consequently sets the stage for increased absenteeism. Guérin et al. (1997) observed that organisational culture influences the intensity of the work-family conflict: if the employee does not feel that he/she will be penalised because of family matters, he/she is less likely to experience work-family conflict. Conflict is also lessened when the employee believes that the manager feels empathy or accepts arrangements in order to facilitate work-life balance. Without a supportive organisational culture and management's acceptance of arrangements and support, the provision of family-friendly policies does not necessarily lead to better work-life balance outcomes (Bond, 2004; Campbell Clark, 2001; Lewis, 2001). Findings reported by Behson (2005) and by Thompson et al. (1999) underline that the simple fact of implementing family-friendly policies will often turn out to be inefficient when informal support is not provided in the form of a positive attitude from management and when there is an absence of an inspiring work environment, that is, one in which employees need not fear for the advancement of their career should they claim the benefits associated with these policies.

From an organisational point of view, it therefore seems that while much research insists on the availability of family-friendly policies (Duxbury and Higgins, 2003; Conference Board, 1994), organisations can play a positive or negative mediating role in the actual access and use of family-friendly policies, including parental leave (Families and Work Institute, 1998; Fusulier et al., 2006; Fusulier et al., 2008).

Although family-friendly policies are public in Quebec, it appears that their use varies from one organisation to the next, according to the perception of the policies by the employees and the anticipated consequences on their careers. The employer's support therefore appears to be an essential ingredient in the success of the parental leave. It also seems that perceived organisational support of parental leave is encourages, discourages or even deters employees from making use of the policies. In order for policies to fulfil their objectives, it is therefore necessary that employed parents be confident that they can make use of the policies without fear of consequences on their career.

We may therefore make the hypothesis that support within the work environment plays a significant role in the perception of parental leave held by the members of the police force under study. In order to assess the informal support within the work environment, studies quoted thus far (Behson, 2005; Guérin et al., 1997; Thompson et al., 1999) have focused on the support by colleagues and managers, and on the career impact that making use of family-friendly policies can have. This research looks at the same factors but our intention is to take the analysis further and to study the effect of parental leave on the employee's career as perceived by persons who went on parental 
IJSSP

$30,9 / 10$

536 leave and by those who did not. The study is of course based on perceptions, but it nevertheless gives a good indication as to the impact of these policies.

The police work environment is not generally thought of as a job environment that encourages or promotes work-life balance. Indeed the police work environment is, with its stress factors, professional risks and variable work schedules, a highly demanding one. Work-life balance concerns are similar in other police organisations in Canada and elsewhere, at least insofar as the workforce includes a good percentage of young workers and of women, and the subject has come up in collective bargaining elsewhere in Canadian cities (for example, Gatineau). The police force is traditionally a male environment but one of the significant trends in its evolution is the feminisation of a large segment of the workforce over the last 20 years. In addition, it appears that younger generations attach more importance to work-life balance than older generations, even at the expense of their career expectations (Labrèche and Lavoie, 2004). Furthermore, younger generations are more open to role sharing between men and women and this includes going on parental leave.

\section{Methodology}

Presentation of the sample

In the police service we studied (Service de police de la Ville de Montréal - SPVM), women represented about 28 per cent of the police workforce in 2006, a 6 per cent increase from 2001 (Vallière and Lavoie, 2006). Moreover, the civilian workforce at the SPVM has long been feminised; the total SPVM workforce had 36 per cent of women in 2006 (Vallière and Lavoie, 2006). In spite of this progress in terms of numbers, women are still mainly found in administrative and support jobs or functions (Lavoie, 2005). Another salient trend is the renewal of the working force. In 2006, 65 per cent of the SPVM employees were born after 1965. Both the increased presence of women and the younger employees contribute to the emergence of new issues and expectations among police forces, especially with respect to work-life balance.

The Montreal police noted an increase not only in maternity leave but also in paternity leave, and in parental leave generally. What's more, the expectation is that the number of days of absence relating to this type of leave will continue to increase in the coming years (Vallière and Lavoie, 2006). This is understandable since there are a greater number of younger women (under 40) in the police force; they are the object of protective re-assignment when pregnant.

Family concerns are among the increasingly important issues for police employees. According to Lavoie (2005), almost two-thirds of police employees believe that their supervisors support them in their efforts to attain work-life balance. In parallel, Labrèche and Lavoie (2004) observe that the integration of women in the police force is constantly improving. Although significant progress has been made, there are still problems regarding work-life balance. A survey carried out in 2005 indicates that 96 per cent of police employees believe that their employer does well in its concern for work-life balance (Lavoie, 2005). Indeed, for 61 per cent of the participants, planning one's career is conditioned by work-life balance. However, 40 per cent of policewomen and policemen declare that they are faced with work-family conflict.

\section{Data collection and analysis}

Our research is based on questionnaires administered online for the most part but also by post (upon request). The survey was carried out in 2007 with the support of the human resources management. A questionnaire was e-mailed to all the members of the 
police force and 206 usable replies were retrieved - 106 from men and 100 from women[1]. Women were therefore overrepresented in our survey (36 per cent of the workforce). The questionnaire was also submitted to administrative employees, a majority of which are women (this category of workers is subject to variable work schedules and high stress even though they are not policewomen). The survey included questions on the existence of family-friendly policies; work-family conflict in general; and on the support provided in terms of taking parental leave. More specifically, our questions delved into five dimensions of perceived workplace support for going on parental leave; dimensions based on previous research (Behson, 2005; Guérin et al., 1997; Thompson et al., 1999):

(1) the possibility to miss work for parental reasons;

(2) the support of the supervisor to go on parental leave;

(3) the support of colleagues to go on parental leave;

(4) the organisational culture with regards to parental leave; and

(5) the negative impacts of parental leave on the career.

In order to draft the questions, we drew on earlier research (Chenevier, 1996; Guérin et al., 1997; Families and Work Institute, 1998; Caussignac, 2000; Tremblay, 2005) that dealt with the support of the management and colleagues for work-life balance (e.g. If I go on parental leave, I have the support of my supervisor). Regarding the perception of parental leave, we wanted to assess separately the opinion of those who had used parental leave and compare that with the opinion of persons who had never used it. For all the dimensions, we compared the answers of those respondents who actually went on parental leave with the answers of those who did not. While the logic of asking these two groups the same questions may lend itself to debate we chose this approach as our study deals with the perception of the respondents and our goal was to assess if the perception of organisational support by employees is different depending on whether they used the programme or not. We did not intend to assess the programme itself by asking only those who used it.

For most questions, we used Likert's scales in four points[2]. The scales thus included the following anchors: totally disagree (1), disagree (2), agree (3) and totally agree (4). We used analysis of variance (ANOVA) (SPSS) to compare the two groups. The research project also included 52 interviews with police men and women. Although we do not refer to these directly here, the interviews confirm the quantitative data, while offering qualitative views and informing us further on the issue (Tremblay et al., 2009).

\section{Findings}

Our data analysis unveiled an interesting result: there are significant differences between the perception of respondents who have experienced parental leave and respondents who have not. Gender remains a central differentiating factor for parental leave. Table I shows the proportion of men and of women among our respondents who

\begin{tabular}{|c|c|c|c|c|}
\hline & No previous leave taken & $\begin{array}{l}\text { Parental leave } \\
\text { Previous leave taken }\end{array}$ & Total & \\
\hline $\begin{array}{l}\text { Men } \\
\text { Women }\end{array}$ & $\begin{array}{l}90 \\
71\end{array}$ & $\begin{array}{l}16 \\
29\end{array}$ & $\begin{array}{l}106 \\
100\end{array}$ & $\begin{array}{l}\text { Table I. } \\
\text { Rate of take-up of }\end{array}$ \\
\hline Total & 161 & 45 & 206 & and women \\
\hline
\end{tabular}


IJSSP

$30,9 / 10$

538 have gone on parental leave. More than 15 per cent of men and 29 per cent of women in our sample have already gone on parental leave. The results obtained in our study are coherent with provincial and national figures published by the province of Quebec and Canada (Doucet et al., 2009): study after study, it is clear that women are the main users of parental leave (85-90 per cent of working women who have children do take leave). Quebec fathers tend to use it as well, but not as long, as mentioned above.

Given that few of our male respondents had gone on parental leave, it was not relevant to provide a distribution according to gender.

\section{An unlikely environment for work-life balance, yet with a globally positive perception of parental leave}

Generally speaking, our participants do not perceive their work environment as well adapted to work-life balance. The overall organisational support for work-life balance is perceived as quite low. Indeed, to the proposition "I feel that my professional environment is attentive to work-life balance", nearly half of our respondents express their disagreement. We conclude that opinions are roughly even regarding work-life balance in the police force.

Nevertheless, the attitude of participants toward parental leave is extremely positive (see Table II for means and standard deviations). Approximately 65 per cent agree with the statement that "it's in the culture that the leave be taken"; and more than 80 per cent believe they had or would have the support of their supervisors and colleagues to take it. The results we gathered actually indicate that the police force work environment is a priori rather favourable to taking up various forms of parental leave (maternity leave, paternity leave and parental leave). The results overall lead us to believe that the police sector, although it is not particularly suited to work-life balance, is relatively open to parental leave. However, we encounter discrepancies in attitudes toward parental leave. There is actually a difference of perception between discourse and first-hand experience of parents who have gone on parental leave.

\section{Respondents who have gone on parental leave have a less positive opinion}

Although the perception of parental leave is generally positive, statistically significant differences are observed between participants who have gone on parental leave and those who have not. In fact, persons who have gone on parental leave have a less positive opinion of the organisational support actually provided, which is interesting, although it of course remains the perception of the individuals. Given the many statements used in the analysis, these perceptions appear quite solid.

Our results indicate that having gone on parental leave is negatively correlated to all the dimensions of the perceived organisational support for parental leave (see Table III): supervisor's support (-0.295), colleagues' support $(-0.176)$, organisational culture $(-0.211)$ and negative impacts on the career $(-0.349)$. The negative impacts of parental

\begin{tabular}{lccccr}
\hline Should I go on parental leave? & $n$ & Min & Max. & Mean & S.D. \\
\hline I can find a way to miss work & 182 & 1 & 4 & 2.98 & 0.739 \\
I have my supervisor's support & 181 & 1 & 4 & 3.03 & 0.710 \\
I have my colleagues' support & 182 & 1 & 4 & 2.97 & 0.765 \\
It's in the culture that the leave be taken & 181 & 1 & 4 & 2.70 & 0.870 \\
There are no negative impacts on my career & 184 & 1 & 4 & 2.69 & 0.909 \\
\hline
\end{tabular}

Table II.

Descriptive statistics 


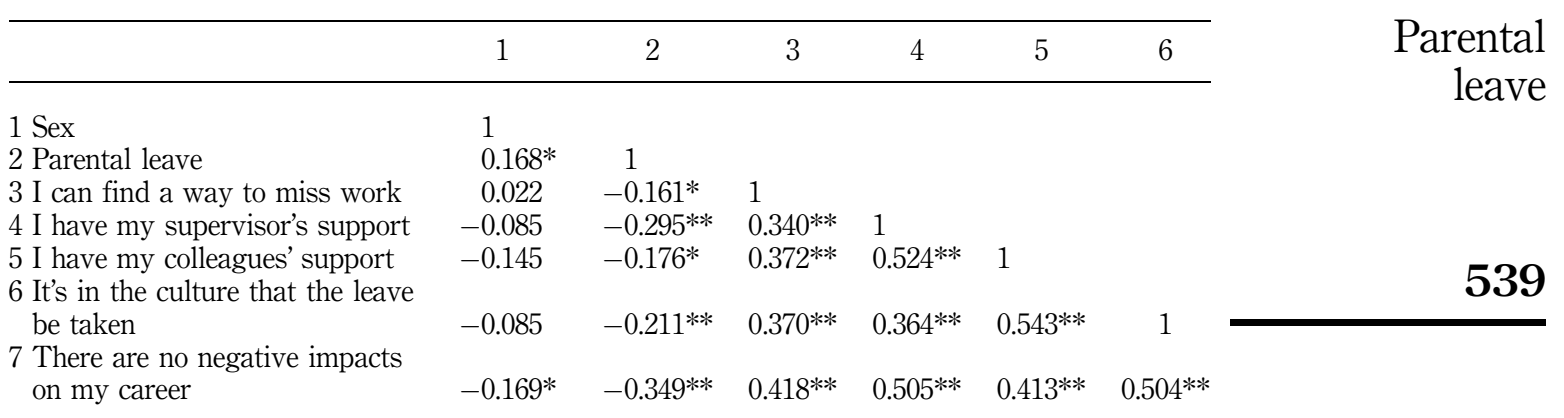

Notes: *Significance at $0.005 ; * *$ significance at 0.001

Table III.

Correlations

leave on the career are also correlated to gender i.e. women in general are more liable than men to consider that parental leave has negative impacts on their career. The correlation is stronger between the actual use of parental leave and the negative impacts perceived on one's career.

The results of the ANOVAs comparing the two groups- those who went on parental leave and those who did not - show that there are significant differences on three dimensions:

(1) the supervisor's support;

(2) the organisational culture; and

(3) the negative impacts on the career (see Table IV).

\begin{tabular}{|c|c|c|c|c|c|c|}
\hline & Sum of square & $\mathrm{DF}$ & Mean of squares & $F$ & Sig. & \\
\hline \multicolumn{7}{|c|}{ 3. I can find a way to miss work } \\
\hline Inter-groups & 2.578 & 1 & 2.578 & 4.816 & 0.029 & \\
\hline Intra-groups & 96.372 & 180 & 0.535 & & & \\
\hline Total & 98.951 & 181 & & & & \\
\hline \multicolumn{7}{|c|}{ 4. I have my supervisor's support } \\
\hline Inter-groups & 7.895 & 1 & 7.895 & 17.034 & 0.000 & \\
\hline Intra-groups & 82.967 & 179 & 0.464 & & & \\
\hline Total & 90.862 & 180 & & & & \\
\hline \multicolumn{7}{|c|}{ 5. I have my colleagues' support } \\
\hline Inter-groups & 3.265 & 1 & 3.265 & 5.732 & 0.018 & \\
\hline Intra-groups & 102.537 & 180 & 0.570 & & & \\
\hline Total & 105.802 & 181 & & & & \\
\hline \multicolumn{7}{|c|}{ 6. It's in the culture that the leave be taken } \\
\hline Inter-groups & 6.070 & 1 & 6.070 & 8.344 & 0.004 & \\
\hline Intra-groups & 130.217 & 179 & 0.727 & & & \\
\hline Total & 136.287 & 180 & & & & \\
\hline \multicolumn{7}{|c|}{ 7. There are no negative impacts on my career } \\
\hline Inter-groups & 18.473 & 1 & 18.473 & 25.304 & 0.000 & \\
\hline Intra-groups & 132.869 & 182 & 0.730 & & & Table IV. \\
\hline Total & 151.342 & 183 & & & & ANOVA \\
\hline
\end{tabular}


IJSSP

$30,9 / 10$

More than 91 per cent of respondents who have never gone on parental leave are convinced that they would have their supervisor's support to take it and only 9 per cent of them think they would not. On the contrary, amongst persons who have gone on parental leave, half are convinced they received support from their supervisor and the other half think they did not have their supervisor's support, a rather high proportion. Important discrepancies are therefore observed in the perceptions of supervisors' support toward parental leave. Respondents who have never gone on parental leave are definitely more optimistic than their colleagues who have experienced the programme.

We have seen that organisational culture is a rather important element to support or disrupt work-life balance. With respect to organisational culture, opinions are almost evenly distributed among persons having gone on parental leave (half of them agree that organisational culture promotes parental leave). Perception is once more dependent on whether respondents have gone on parental leave or not and statistical tests show significant differences between groups. Respondents who have not gone on parental leave mostly believe that it is in the organisational culture to take it (69 per cent agree with the statement, including 18 per cent who are in total agreement). On the other hand, nearly one-quarter of those who have gone on parental leave totally disagree with the statement. Persons who have gone on parental leave have a less favourable opinion of organisational culture concerning the taking up of parental leave. Respondents who did not go on parental leave, for their part, do not have a firsthand experience of the issue and their perception is that workplace culture is very supportive for parental leave. Such differences in the perception of organisational culture regarding parental leave show that problems occur for parents who go on parental leave despite the organisational evolution in this respect over the years.

Finally, the question regarding the impact of parental leave on one's career shows very significant differences between the groups. Overall, two-thirds of respondents agree with the statement that "there are no negative impacts on my career". Again, significant differences appear between respondents who have gone on parental leave and those who have not. The former disagree with the statement in a larger proportion; less than one-third are convinced that going on parental leave does not have negative impacts on one's career. A large majority of respondents (71 per cent) who have gone on parental leave are convinced that parental leave has a (potentially) negative impact on their career while 73 per cent of respondents who have not gone on parental leave think the opposite. This finding clearly underlines the differences in the perception of persons with and without experience of the parental leave programme.

Until respondents have been actually confronted with the problems involved in going on parental leave, especially where their career is concerned, they do not have a negative perception of the issue of parental leave. The work environment does not seem reluctant regarding parental leave, but our results clearly show that persons who have gone on parental leave still have the feeling that there is a price to pay in terms of their career. Indeed, more than two-thirds of them are convinced that parental leave has a negative impact on one's career.

\section{Conclusion}

Our results question the application of a given social policy: parental leave. They show that there are substantially important differences between the perception of parental leave by those who have not taken leave and the experience of those who have. The former have a rather positive perception of the organisational support they would 
receive should they go on parental leave. For the latter, however, perceptions are mixed. The hands-on experience with parental leave has no doubt driven them to re-evaluate the level of organisational support they received to go on parental leave. The majority of employees who have already gone on parental leave believe that there are negative impacts on one's career.

People who have not gone on parental leave seem much more optimistic regarding the organisational support offered by supervisors and the organisation in general than those who have already taken parental leave. It is possible that a manager who has not gone on parental leave would offer less support than a manager who has, simply because the former is unaware of the difficulties actually facing the employees who take this leave.

Our results clearly show that the simple implementation of a family-friendly policy, such as parental leave, will not necessarily lead to better work-life balance outcomes without appropriate organisational support. This confirms the importance of organisation support suggested in earlier research (Behson, 2005; Bond, 2004; Campbell Clark, 2001; Lewis, 2001; Thompson et al., 1999) that did not look at a specific social policy. These results draw attention to the role that needs to be played by organisations and managers alike to alleviate the persistent difficulties facing workers who go on parental leave - especially when returning to paid employment - if this innovative policy is to have really positive impacts. Moreover, it is only after going on parental leave that parents realise the negative impact of the leave on their career. This should convince organisations to prepare for the return of employees from parental leave and provide the support they need to prevent the negative impacts on their careers. It should also encourage policy makers to try to consider the possible negative impacts of such a social policy on individuals, and especially on women. Without resolving these issues, the parental leave policy will not attain its objectives which consist in balancing work and family roles between mothers and fathers. Indeed, it could even reinforce existing tendencies toward the gender specialisation of roles and block the upward movement of women who go on parental leave more often than men and do so for longer periods (Moss and O'Brien, 2006; Tremblay, 2003, 2004). The paid parental leave policy, which has up to now been considered as significant progress toward professional equality, may end up reinforcing women's traditional role with regards to childcare without having a significant effect on the father's role. Overall, the global effect of this policy on women's contribution to the labour market would therefore turn out to be rather negative with respect to professional equity (Doucet et al., 2009). Policy design and follow-up on policy impacts is therefore crucial, especially when it comes to gender equality (Lewis and Campbell, 2008).

In keeping with the above observation, the province of Quebec designed a more flexible policy than Canada with higher compensation and more leave for the father, and this has had a positive impact on father's take up of parental leave. Yet, as shown in the results of our study, it seems that going on parental leave may still have negative impacts on one's career and further investigation is thus required in order to better understand the workplace issues involved with these policies and measures and make them as efficient as possible. Consequently, it is also important to follow the actual use of the policy to make sure it does not have negative impacts for those who use it.

Although our findings are limited to the sector involved in our study, i.e. the police sector, the results may be valid for other sectors as well, since the use of parental leave concerns all sectors, and this is something we will pursue in our future research. 
IJSSP

$30,9 / 10$

542

\section{Notes}

1. The response rate is of 5 per cent if we calculate on the whole workforce. This may appear very low, but the HRM Department has indicated that many employees do not use the professional e-mail, so that many probably never saw the invitation to answer the questionnaire. The response rate is also weak on questions relating directly to parental leave because non-parents probably felt that they were not directly concerned by the issue.

2. In the case of perceptions, it appeared preferable to not offer a neutral option. Had there been a neutral point in the scale, non-parents may have opted for this option, while our purpose was to have their opinion on the matter.

\section{References}

Allard, K., Haas, L. and Hwang, P. (2007), "Exploring the paradox: experiences of flexible working arrangements and work-family conflict among managerial fathers in Sweden", Community, Work \& Family, Vol. 10 No. 4, pp. 475-93.

Almey, M. (2007), Women in Canada: Work Chapter Updates, Statistics Canada, Ottawa.

Behson, S.J. (2005), "The relative contribution of formal and informal organizational work-family support”, Journal of Vocational Behavior, Vol. 66 No. 3, pp. 487-500.

Bond, S. (2004), "Organisational culture and work-life conflict in the UK", International Journal of Sociology and Social Policy, Vol. 24 No. 12, pp. 1-24.

Budd, J.W. and Mumford, K.A. (2006), "Family-friendly work practices in Britain: availability and perceived accessibility", Human Resource Management, Vol. 45 No. 1, pp. 23-42.

Campbell Clark, S. (2001), "Work cultures and work/family balance", Journal of Vocational Behavior, Vol. 58 No. 3, pp. 348-65.

Caussignac, E. (2000), La nature des liens entre les déterminants du conflit emploi-famille, son ampleur et ses impacts, Ecole des Hautes Etudes Commerciales, Montréal.

Cette, G., Méda, D., Sylvain, A. and Tremblay, D.G. (2007), "Activité d'emploi et difficultés de conciliation emploi-famille: une comparaison fine des taux d'activité en France et au Canada", Loisir et société/Leisure and Society, Vol. 29 No. 1, pp. 117-54.

Chenevier, L. (1996), Les variables influencant l'ampleur du conflit emploi-famille ressenti par l'employé(e), Ecole des Hautes Etudes Commerciales, Montréal, p. 172.

Conference Board of Canada (1994), Concilier le travail et la famille: enjeux et options, Conference Board du Canada, Ottawa.

Conseil de la Famille et de l'Enfance (2008), L'engagement des pères, Rapport 2007-2008, Conseil de la Famille et de l'Enfance, Quebec.

Doucet, A., McKay, L. and Tremblay, D.-G. (2009), "Parental leave in Canada and Quebec: how to explain the different routes taken?", in Moss, P. and Kamerman, S. (Eds), The Politics of Parental Leave Policies, Policy Press, Bristol.

Duxbury, L. and Higgins, C. (2003), Where to Work in Canada? An Examination of Regional Differences in Work Life Practices, CPRN Research Report commissioned by the BC WorkLife Summit 2003, Ottawa, p. 103.

Duxbury, L., Higgins, C. and Lee, C. (1993), "The impact of job type and family type on workfamily conflict and perceived stress: a comparative analysis", Ressources Humaines, ASAC'93, Vol. 14 No. 9, pp. 21-9.

Elliott, J., Dale, A. and Egerton, M. (2001), “The influence of qualifications on women's work histories, employment status and occupational attainment at age 33", European Sociological Review, Vol. 17 No. 2, pp. 145-68.

Families and Work Institute (1998), 1998 Business Work-life Study, Families and Work Institute, New York, NY. 
Frederick, J.A. (1995), Au fil des heures ... L'emploi du temps des Canadiens, Statistique Canada, Ottawa.

Frederick, J.A. and Fast, J.E. (2001), "Enjoying work: an effective strategy in the struggle to juggle?", Canadian Social Trends, Statistics Canada, Ottawa.

Frone, M. and Rice, R. (1987), "Work-family conflict: the effect of job and family involvement", Journal of Occupational Behaviour, Vol. 8, pp. 45-53.

Fusulier, B., Giraldo, S. and Lanoy, D. (2006), "L'utilisation des dispositifs d'articulation de la vie familiale et de la vie professionnelle. Étude auprès de 48 entreprises de Wallonie (Belgique)", Enfance, famille et génération, Vol. 1 No. 2, pp. 1-21.

Fusulier, B., Tremblay, D.-G. and di Loreto, M. (2008), "La conciliation emploi-famille dans le secteur du travail social au Quebec : une différence de genre. Quelques éléments de réponse", Politiques sociales, Vol. 68 No. 1, pp. 105-21.

Galinsky, E., Kim, S.S. and Bond, J.T. (2001), Feeling Overworked: When Work Becomes too MuchExecutive Summary, Families and Work Institute, New York, NY.

Greenhaus, J.H. and Beutell, N. (1985), "Sources of conflict between work and family roles", Academy of Management Review, Vol. 10 No. 1, pp.76-88.

Guérin, G., St-Onge, S., Chevalier, L., Denault, K. and Deschamps, M. (1997), Le conflit emploifamille: ses causes et ses conséquences: résultats d'enquête, Université de Montréal, École des Relations Industrielles, Montréal.

Haas, L., Allard, K. and Hwang, P. (2002), “The impact of organizational culture on men's use of parental leave in Sweden”, Community, Work \& Family, Vol. 5 No. 3, pp. 319-41.

Kossek, E.E. and Ozeki, C. (1998), "Work-family conflict, policies, and the job-life satisfaction relationship: a review and directions for organizational behavior-human resources research", Journal of Applied Psychology, Vol. 83 No. 2, pp. 139-49.

Labrèche, I. and Lavoie, V. (2004), Pour aller plus loin ensemble. Réalités Policières: Portrait 2004, SPVM, Montréal.

Lavoie, V. (2005), Conciliation Famille/Travail: Portrait 2004, SPVM, Montréal.

Lewis, J. and Campbell, M. (2008), "What's in a name? 'Work and family' or 'work and life' balance policies in the UK since 1997 and the implications for the pursuit of gender equality”, Social Policy \& Administration, Vol. 42 No. 5, pp. 524-41.

Lewis, S. (2001), "Restructuring workplace cultures: the ultimate work-family challenge?", Women in Management Review, Vol. 16 No. 1, pp. 21-9.

Marshall, K. (2003), "Benefiting from extended parental leave”, Perspectives on Labour and Income, Vol. 4 No. 3, March, Statistics Canada Catalogue No. 75-001-XIE, pp. 5-11 (accessed 14 July 2010).

Marshall, K. (2006), “Converging gender roles”, (PDF), Perspectives on Labour and Income, Vol. 7 No. 7, July, Statistics Canada Catalogue No. 75-001-XIE, pp. 5-17 (accessed 20 May 2008).

Marshall, K. (2008), "Fathers' use of paid parental leave”, Perspectives - Statistics Canada, Statistics Canada Catalogue No. 75-001-X, Vol. 9, June, pp. 5-14.

Moss, P. and O'Brien, M. (2006), International Review of Leave Policies and Related Research, No. 57, ERRSN, Department of Trade and Industry, London, p. 241.

Rothbard, N., Philips, K. and Dumas, T. (2005), "Managing multiple role: work-family policies and individual's desire for segmentation”, Organization Sciences, Vol. 16 No. 3, pp. 243-58.

Stephens, G.K. and Sommer, S.M. (1996), "The measurement of work to family conflict", Educational and Psychological Measurement, Vol. 56 No. 3, pp. 475-86.

Thompson, C.A., Beauvais, L.L. and Lyness, K.S. (1999), "When work-family benefits are not enough: the influence of work-family culture on benefit utilization, organizational attachment, and work-family conflict", Journal of Vocational Behavior, Vol. 54, pp. 392-415. 
IJSSP

$30,9 / 10$

544
Tremblay, D.-G. (2003), “Articulation emploi-famille: comment les pères voient-ils les choses?”, Politiques Sociales, Vol. 63 Nos 3/4, Automne, pp. 70-86.

Tremblay, D.-G. (2004), "Articulation emploi-famille et temps de travail: les usages différenciés du temps chez les pères et les mères”, Nouvelles Pratiques Sociales, Vol. 16 No. 1, pp. 76-93.

Tremblay, D.-G. (2005), "La conciliation emploi-famille et les temps sociaux; le Québec en comparaison d'autres pays", dans Tremblay, D.-G. (2005, sous la dir), De la conciliation emploi-famille à une politique des temps sociaux, Presses de l'université du Québec, Collection Économie politique, Québec, pp. 231-58.

Tremblay, D.-G. (2009), “Quebec's policies for work-family balance: a model for Canada?”, in Cohen, M. and Pulkingham, J. (Eds), Public Policy for Women. The State, Income Security and Labour Market Issues, University of Toronto Press, Toronto, pp. 271-90.

Tremblay, D.-G., Genin, É. and Di Loreto, M. (2009), Le congé parental et les autres congés familiaux: un droit ou un privilège? Une analyse dans le secteur policier, Chaire de recherche sur les enjeux socio-organisationnels de l'économie du savoir, Teluq-UQAM, Montréal.

Vallière, S. and Lavoie, V. (2006), Rapport sur les tendances internes et externes en matière de ressources humaines, SPVM, Montréal.

\section{Corresponding author}

Diane-Gabrielle Tremblay can be contacted at: dgtrembl@teluq.uqam.ca

To purchase reprints of this article please e-mail: reprints@emeraldinsight.com Or visit our web site for further details: www.emeraldinsight.com/reprints 
Reproduced with permission of the copyright owner. Further reproduction prohibited without permission. 